\title{
Polityka socjalna i sytuacja ludzi w podeszłym wieku
}

Od pewnego czasu daje się zauważyć wzmożone zainteresowanie zjawiskiem starzenia się populacji i jego konsekwencjami na poziomie społecznym, politycznym i kulturowym, które dotyczą zarówno Europy, jak i całego świata. Można przypuszczać, że zainteresowanie „trzecim wiekiem” jest wyrazem chęci poprawiania jakości życia społeczeństwa w ogóle, dzięki czemu zaawansowani wiekowo obywatele w przyszłości nie powinni odczuwać negatywnych efektów osamotnienia i cierpienia, wywołanego chorobami i uchybieniami moralnymi ze strony innych.

Z drugiej strony również wszyscy ci, którym daleko jeszcze do starości, powinni się uczyć jak należałoby się starzeć, biorąc pod uwagę, że zjawisko życia jest procesem dynamicznym i niezwiązanym tylko $\mathrm{z}$ dniem dzisiejszym, ale z jutrem, które bardzo szybko nadejdzie i nie powinno zastać nas nieprzygotowanych.

\section{Problem ogólnoświatowy}

Człowiek stary stanowi dla nas wszystkich (a raczej powinien stanowić) wielką wartość, która powinna nas inspirować, z którego rad powinniśmy korzystać w najtrudniejszych momentach naszego życia. Nie można zrywać z przeszłością ani też jej negować bez wcześniejszego jej zrozumienia. Najbardziej zaawansowane cywilizacje i rzeczywisty postęp są zawsze rezultatem ciągłości pomiędzy przeszłością i teraźniejszością, pomiędzy tradycją i nowoczesnością. Ileż mądrości traci społeczeństwo, lekceważąc doświadczenie ludzi starych zdobywane w ciągu ich długiego życia? ${ }^{1}$

Panujący dziś powszechnie mit konieczności posiadania, i to posiadania coraz więcej, również za cenę gwałcenia praw natury i podporządkowywania sobie człowieka, niszczy dawne poczucie obowiązku wobec drugiego człowieka, rów-

Pontificium Consilium pro Laicis, La dignità dell'anziano e la missione nella Chiesa e nel mondo, Città del Vaticano 1998, s. 15. 
nież tego najbliższego. Podstawowe potrzeby mylone są z efemerycznymi pragnieniami, które zawsze stwarzają poczucie niedosytu i braku szczęścia u tych, którzy zapracowują się w pogoni za chęcią ich zaspokojenia. ${ }^{2}$ Człowiek sam siebie redukuje do roli narzędzia całkowicie zdanego na kaprysy wyimaginowanych, rzadziej rzeczywistych, potrzeb. Osoby stare, które nabyły w ciągu swojego długiego życia wiedzę o prawdziwym znaczeniu ludzkiej egzystencji powinny być dla osób młodych nauczycielami „życia”, reprezentującymi prawdziwe wartości. Obcując z nimi ludzie młodzi targani licznymi dylematami, z pewnością nauczyliby się, jak uniknąć błędów i nabyć bardziej krytycznego spojrzenia na rzeczywistość.

Ogłoszony Rok Ludzi Starych rok 2002 do obecnej chwili przypomina osobom wrażliwym o problemach związanych z zaawansowanym wiekiem. Sam fakt, że zwrócono uwagę opinii światowej na problem starości z pewnością jest bardzo ważny, gdyż przypomina, że obowiązkiem społeczeństwa jest zapewnienie wszystkim, a więc także ludziom starym, godnej egzystencji.

Niezależnie od różnic w polityce socjalnej poszczególnych państw na świecie i priorytetów, którymi się one kierują, dostrzega się w niej wspólny wszystkim element, który ludzie dobrej woli powinni być zawsze gotowi uznać i realizować starość jako wartość.

Musimy jednak dokonać prawdziwej rewolucji kulturowej, aby 1 października każdego roku ${ }^{3}$ nie pozostał pustym rytuałem, ale stał się nowym stylem przeżywania mijających lat z poszanowaniem godności każdego czlowieka, każdego dnia i w każdym miejscu. Należałoby, więc przeorganizować nasze życie rodzinne i społeczne w taki sposób, aby każdy dzień stał się dniem człowieka starego.

Aby tak się stało, należy mieć świadomość zachodzących zmian. Na przykład, że niektóre z naszych społeczeństw w jednej czwartej składają się już z osób po sześćdziesiątce. To powinno skłaniać do dalekowzrocznej polityki społecznej, nastawionej na usprawnianie dostępu do niezbędnych świadczeń socjalnych przy współpracy instytucji państwowych, społecznych i wolontariatu.

Obok akcji niesienia pomocy (również ekonomicznej) rodzinom zamierzającym otoczyć opieką osoby stare, nie można pominąć tych seniorów, którzy chcieliby zamieszkać w przystosowanych i wyspecjalizowanych instytucjach (powszechnie nazywanych domami spokojnej starości), nastawionych na zaspakajanie stawianych przez nich pewnych wymagań natury fizycznej i psychicznej. W ten sposób należy wyjść naprzeciw oczekiwaniom wielu tych, którzy (np. nauczeni doświadczeniem) nie do końca są przekonani, iż tylko rodzina jest w stanie rozwiązać liczne problemy wynikające z zaawansowanego wieku. Poza tym jest wiele rodzin, które

2 Cfr. E. Fizzot Ti, Nel cavo della mano. Agli anziani, Edizioni Salcom, Canonica 1990, s. 9.

3 1 października ONZ ustanowiła Międzynarodowym Dniem Osób Starszych. Cfr. http://www. un.org.pl/rozwoj/aktualnosci.php?nid=445 
nie mogą pozwolić sobie na przygarnięcie osoby wymagającej specjalnej opieki, chociażby z racji wieku i gnębiących ją dolegliwości wymagających specjalistycznej aparatury. W każdym razie $w$ chwili obecnej wielu ludzi starych żyje samotnie. Jak długo jednak będą jeszcze w stanie sami zadbać o siebie; na ile będą autonomiczni i samowystarczalni? Czy w ich sytuacji wystarczy jedynie sporadyczny kontakt telefoniczny albo okresowe wizyty sąsiadów? Godne dźwiganie ciężaru lat (bez ujmowania niczego z ich wartości) czasami wymaga też czegoś więcej niż tylko przyjaźni, a mianowicie aktywności, która pozwala czuć się potrzebnym, rozumianym i kochanym. Potrzebne są również miejsca wyposażone w nowoczesne urządzenia, które sprzyjają refleksji, modlitwie, umożliwiają poruszanie się, rehabilitację, hospitalizację, a nawet umieranie.

\section{Kształcenie dorosłych}

To wszystko wymaga m.in. również zmiany świadomości społecznej w odniesieniu do ludzi starych, jak równieź świadomości tkwiącej w nich samych. Należy, więc zadbać również o edukację dorosłych. ${ }^{4}$ Wiadomo, że edukacja jest procesem ustawicznym i opiera się na fundamentalnym prawie człowieka do samorealizacji, przyczyniając się jednocześnie do globalnego rozwoju społeczności, której częścią jest każdy z nas.

Doświadczenie osób starszych pozwala młodemu pokoleniu łatwiej kroczyć trudną drogą odkrywania i budowania własnej tożsamości. Pozbawieni autorytatywnego i pozytywnie do nich nastawionego przewodnika ryzykują zmarnowaniem swojej przyszłości i narażeni są na błądzenie po krętych ścieżkach życia oraz na niepowodzenia osobiste i zawodowe. Bez pomocy dorosłych, bez analizowania i pokonywania wątpliwości, bez krytycznej oceny konsekwencji podejmowanych decyzji i postępowania, młodzi z trudnością dochodzą do poziomu logiczno-abstrakcyjnego myślenia. Ponadto potrzebują przede wszystkim wychowania, które pomoże im odkryć autentyczne znaczenie ich egzystencji. Zbyt wiele jest pokus powszechnego dziś konsumizmu dla tych, którzy nie mają jeszcze ugruntowanej świadomości moralnej. ${ }^{5}$ Stąd rodzice i dziadkowie powinni angażować się w to niełatwe zadanie, mogące również ich ubogacié wewnętrznie i przysporzyć im wiele satysfakcji. Należy, więc sobie życzyć, aby społeczeństwo nabywało tej świadomości pedagogicznej i przyczyniło się do wspomagania ludzi starych, którzy są „dorosłymi zaawansowanymi w latach”.

\footnotetext{
4 Cfr. L. Baracco, La famiglia e gli anziani. Per un rapporto «nuovo», ELLE DI CI, Leumann 1991, s. 14-15; Pontificium Consilium pro Laicis, La dignità dellanziano e la missione nella Chiesa e nel mondo, Città del Vaticano 1998, s. 27.

5 Cfr. L. Baracco, La famiglia ..., s. 13-14.
} 
Osoby stare muszą być akceptowane przez całą społeczność. Wymaga tego zarówno obowiązek solidarności społecznej, jak i konieczność zwrócenia uwagi na tych, którzy w okresie swej aktywności zawodowej, dzięki zdobytym kompetencjom i dobrej woli, tak wiele dali innym. W tym miejscu warto przypomnieć, że zanim problematyka starzenia się społeczeństw Zachodu pojawiła się na łamach czasopism i w programach telewizyjnych, wielu emerytów znalazło się w sytuacji kryzysowej, a wielu innych kończących obecnie działalność zawodową, poważnie obawia się o swoją przyszłość. Oprócz zabezpieczenia ekonomicznego, pozwalającego godnie żyć, potrzebują oni również warunków do swobodnego realizowania się i rozwijania osobowości na czas, który im pozostał, przy czym nie tyle chodzi tu o zagwarantowanie nabytych praw, ile o uznanie, że jako osoby są "nośnikami” wartości, wymagających ratowania i poszanowania. ${ }^{6}$ Społeczeństwo, które poddaje w wątpliwość te święte prawa, nie jest godne mienić się społeczeństwem cywilizowanym.

\section{Społeczeństwo dziadków}

Publikowane dane demograficzne wykazują, że w historii Europy nie obserwowano jeszcze zjawiska, które tak ewidentnie sugeruje brak woli posiadania dzieci u młodego pokolenia. Już dzisiaj w niektórych krajach na trzech dziadków przypada tylko jeden wnuk. Tak, więc, podczas gdy z jednej strony czas życia ludzi starych wyraźnie się wydłuża, $\mathrm{z}$ drugiej znacznie spada liczba urodzeń. $W$ tej złożonej sytuacji dostrzega się również, że wydłużeniu lat życia towarzyszy obniżanie się jego jakości. Rośnie grupa ludzi samotnych i starych, zamkniętych we własnych czterech ścianach, które utrzymują ścisły kontakt jedynie z telewizją i - okazjonalnie - z najbliższymi krewnymi. To kolejny dowód braku organicznej polityki prorodzinnej. Nawoływania polityków do posiadania liczniejszego potomstwa w celu ratowania ekonomii bez wątpienia są równie sugestywne, co trudne do zaakceptowania, ponieważ społeczeństwo jest w takiej mierze cywilizowane, w jakiej stwarza warunki sprzyjające wychowywaniu dzieci i dożywaniu trudnych lat starości. Osobiste życie człowieka nie może stać się elementem manipulacji ekonomicznych. Bardziej autentyczne życie w przyszłości mogą nam zagwarantować demokratyczne wybory odpowiednich ludzi, którzy zadbają przede wszystkim o poszanowanie wartości ludzkiego życia.

Niewątpliwie rozwiązanie problemu "trzeciego wieku” wymaga prowadzenia specyficznej polityki. Pewnego wsparcia można oczekiwać ze strony poszczególnych ministerstw. Może łatwiej i korzystniej byłoby włączyć inicjatywy zmierzające do uzdrowienia sytuacji ludzi starych w pakiet działań na rzecz szeroko

6 Cfr. L. Baracco, La famiglia ..., s. 18-19. 
rozumianej rodziny, niż rozrzucać je pomiędzy już zbyt liczne kwestie opieki socjalnej. Dzisiejsza niełatwa sytuacja osób w podeszłym wieku jest obrazem naszej rodziny, który wykształcił się pod wpływem licznych czynników ekonomicznych, społecznych, kulturowych i religijnych.

Obok globalnej i przejrzystej polityki, skierowanej na ludzi w podeszłym wieku, stanowiącej integralną część polityki rodzinnej, sugeruje się zwiększenie aktywności instytucji lokalnych, które działając w konkretnych warunkach są w stanie lepiej zrozumieć bieżące potrzeby ludzi starych, mieszkających na podległym im terenie i właściwie na nie odpowiedzieć. Wynika to z oczywistych różnic terytorialnych, wyraźnie uzależnionych od stopnia świadomości społecznej istniejących potrzeb, funkcjonowania organizacji samorządowych, państwowych czy kościelnych oraz dobrej woli ludzi wrażliwych na potrzeby innych.

\section{Prawa seniorów w państwie socjalnym}

W życiu starszego człowieka można dostrzec dwa różne, sukcesywnie następujące po sobie momenty. W pierwszym dostrzega on swe "obowiązki" wobec wnuków, dzieci i własnej rodziny. W tym czasie żyje dla innych i jest przekonany o ważności swojej osoby na miarę posiadanych kompetencji, możliwości i umiejętności. Czuje się potrzebny, jeżeli członkowie rodziny doceniają jego wysiłki.

Po przejściu na emeryturę w konfrontacji z poczynaniami wnuków i dzieci, jego życie zazwyczaj schodzi na drugi plan. Tak zaczyna się proces marginalizacji, zależności i niedołężności fizycznej i psychicznej.?

W obecnych czasach, dzięki ogólnemu podniesieniu poziomu wykształcenia, człowiek stary coraz częściej odkrywa autentyczne znaczenie swoich "praw”, nie tracąc świadomości swoich tradycyjnych „obowiązków” w stosunku do członków rodziny i wspólnoty, której jest częścią.

Powszechna zgoda, co do niektórych wartości moralnych jest jednym z bardziej znaczących wyróżników naszego wieku. Godny podkreślenia jest fakt, że w historycznym kontekście ideologicznego i kulturalnego pluralizmu, jaki obserwujemy obecnie, mimo wszystko dostrzega się znaczenie praw i obowiązków, które są jednocześnie wyrazem głębokiej natury człowieka i wyrazem jego ewolucji historycznej. Nadszedł czas, w którym zaawansowane wiekowo osoby powinny reagować na pasywność, na manipulacje, na uprzedzenia i stereotypy, mając świadomość swoich praw jako ludzie i jako obywatele.

7 Cfr. A. LeszczyńsKa-Rejchert, Czlowiek starszy i jego wspomaganie - w stronę pedagogiki starości, Wyd. UWM, Olsztyn 2005, s. 89-91; Pontificium Consilium pro Laicis, La dignità dell'anziano e la missione nella Chiesa e nel mondo, Città del Vaticano 1998, s. 25-26. 
Na koniec warto zwrócić uwagę, że w obecnych czasach także kryzys ekologiczny staje się jeszcze poważniejszy, ponieważ z biologicznego punktu widzenia, również rozwój gatunku ludzkiego stoi pod znakiem zapytania. Człowiek sam siebie pozbawia własnej wyjątkowości ontologicznej (laicyzacja życia) i zagraża wyjątkowości biologicznej (manipulacje genetyczne); dewaluuje się jego otwarty i solidarny charakter życia.

W specjalistycznych czasopismach, a także w środkach społecznego przekazu bije się na alarm w celu ratowania wymierających gatunków zwierząt, a jednocześnie niewiele robi się dla zagwarantowania moralnie akceptowanych warunków autentycznej „ekologii człowieka”.

Aby zrealizować stawiane przed sobą cele trzeba umacniać prawa starego człowieka, nie ograniczając się tylko do wygłaszania haseł, ale tworząc system gwarancji i warunków, w których prawa te znajdą możliwość realizowania się w Kościele, w szkole, w instytucjach i organizacjach lokalnych, krajowych i międzynarodowych, w rodzinie, $w$ miejscach wypoczynku, w świecie nauki i kultury. W końcu, również bardziej świadoma i stosowna gerontologia ${ }^{8}$ powinna zaangażować się w odzyskiwanie wychowawczych wartości starego człowieka.

Konsumizm, indywidualizm i destruktywna rywalizacja w państwie odwołującym się do solidarności i propagującym dobro wspólne, powinny być rugowane. Należy natomiast podejmować konkretne działania na rzecz osób słabych i będących w potrzebie. ${ }^{9}$ Gwarantowanie im godnego życia w społeczeństwie służy rodzinie i podnosi jakość życia całej wspólnoty. Kiedy polityka nastawiona po prostu na człowieka odkryje moralną, społeczną i chrześcijańską wartość solidarności międzyludzkiej, dostrzeże również pozytywne konsekwencje, przyśpieszające ekonomiczny rozwój państwa.

8 Cfr. A. Leszczyńsra-RejCherT, Człowiek starszy ..., s. 217-218.

9 Nikt nie będzie innych dobrze traktował, dopóki nie przekona się, że jest dobry. Egoizm zmienia życie w trudny do uniesienia ciężar, a tylko altruizm zmienia kłopoty w źródła życia. Cfr. E. Fizzotti, Nel cavo..., s.135. 


\section{SUMMARY}

We have observed great interest in the phenomenon of aging of the population and its consequences. On the hand, all who are much younger should learn how to grow old taking into account that the phenomenon of life is a dynamic process and it is not connected with the present day but the future which will come very fast. That is why, it should not find us unprepared.

Some attention is paid to the problem of aging and social duty of securing old people a decent existence. It requires a change of consciousness regarding old people as well as their own consciousness. It is known that education is a constant process which is based on a fundamental human right to self-realisation. It contributes to global development of society which we are a part of.

Human personal life becomes a subject of economic manipulation. Thus, next to global and clear policy directed to old people, which is a central part of the family policy, increasing activity of the private people and local institutions in using and regaining educational values of the old person presence in family and social life is suggested. 